\title{
Assessment on Peri-Urban Dairy Production System and Evaluation of Quality of Cows' Raw Milk: A Case of Shambu, Fincha and Kombolcha Towns of Horro Guduru Wollega Zone, Ethiopia
}

\author{
Demissu Hundie
}

College of Agricultural Sciences, Wollega University, Shambu Campus, Shambu, Ethiopia

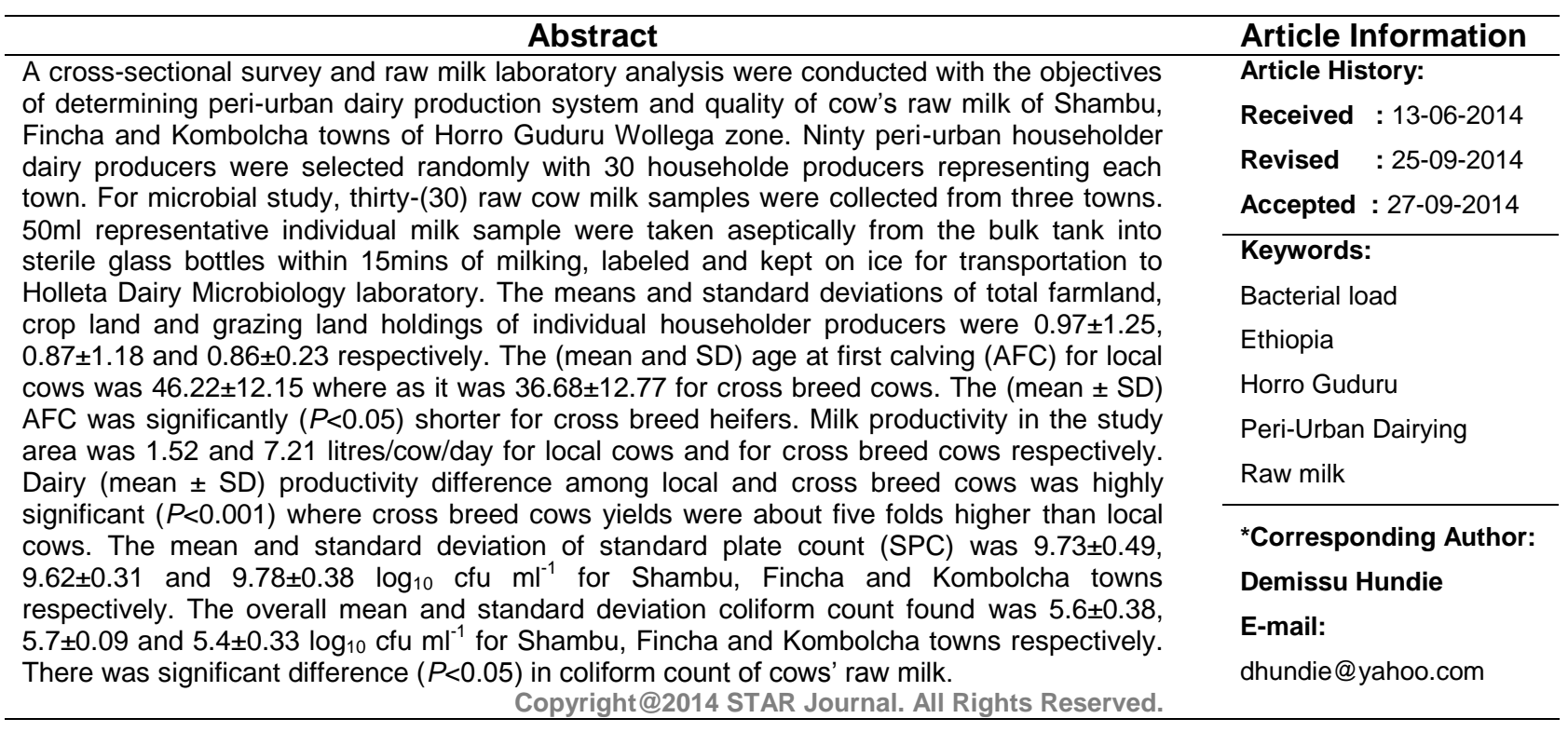

\section{INTRODUCTION}

Ethiopia holds large potential for dairy development due to its large livestock population, favourable climate for improved and high-yielding animal breeds, and the relatively disease-free highland environment. Given the considerable potential for smallholder income and employment generation from high-value dairy products, development of the dairy sector in Ethiopia can contribute a lot to poverty alleviation and nutrition in the country (Mohamed et al., 2004).

The main source of milk production in Ethiopia is from the cow. However, small quantity of milk is also obtained from goat and camel in some regions particularly in pastoralist areas. Four major systems of milk production can be distinguished in the country, which includes; pastoral dairy production system, highland smallholders dairy production system, urban and peri-urban (small and medium dairy farms in backyards in and around towns and cities) dairy production system and intensive dairy farming system (Ketema and Tsehay, 2004).

Urban and peri-urban dairy production systems are among the many forms of dairy production systems in the tropics and sub-tropics. The systems involve the production, processing and marketing of milk and milk products that are channelled to consumers in urban centres (Rey et al., 1993; Staal and Shapiro, 1996). These urban and peri-urban dairy production systems evolved to satisfy the increasing demand for milk in urban centres as a consequence of increasing urbanisation, rising per capita income and increasing cost of imported milk and milk products. They contribute to overall development through income and employment generation, food security, asset accumulation, poverty alleviation and improving human nutrition and health.

More than 90 percent of the urban dairy farmers live in the medium and low-density areas and use their residential units as places where dairying is carried out (Shiferaw et al., 2003 and Mlozi, 2005).

The dairy farmers in these areas have little or no access to grazing land and they rely mainly on purchased feeds and communal grazing lands. This results in dairy cattle receiving sub optimal level of nutrition especially during the dry periods. The areas have limited space for 


\section{Demissu Hundie}

dairying and due to small land holdings, zero grazing is common (Msangi et al., 2005 and Cole, 2008). The level of milk production and reproduction of dairy cattle varies considerably within and between countries and between production systems. The variations are mainly due to ecological conditions, management factors and the way researchers report their findings.

The diet of rural communities is higher in calories but less diversified whereas city dwellers have varied diet that is better in animal proteins and fats, and characterized by higher consumption of meat, poultry, milk and milk products (FAO, 1997). In the high lands of Ethiopia, milk produced by small holders is used for family consumption and for the production of butter and ayib (locally produced cottage cheese). Alganesh, (2002) reported that 9.22 litres of whole milk and $1.8 \mathrm{~kg}$ of butter were sold per interviewed householders per week in the rainy season in Eastern Wollega. Owing to the projected increase of urban population in Ethiopia, the demand for animal products in terms of both quality and quantity is estimated to increase substantially. Post harvest losses of about $40 \%$ milk and its products have been reported from milking to consumption. Such losses are mainly attributed to mishandling in dairy value chain from farm to fork. These include, contamination during milking, long storage time before consumption, deliberate adulteration, substantial handling, transportation and distribution system (CSA, 2010).

The large demand for milk on the one hand and the small supply of milk and milk products for the major urban centres in Ethiopia on the other hand shows the untapped potential for development of urban and peri-urban dairy farms. Cattle are grazing on owned or rented land. Special inputs are linked to the type of genotype and involve artificial insemination and supplementary feeds to grazing and stall-fed roughages. Market-oriented smallholder peri-urban dairy production systems have tremendous potential for development and could play a significant role in minimising the acute shortage of dairy products in urban centres. Current increases in economic pressure, competition for limited resources, enhanced urbanization and market forces have led to an increase in the level of intensification in these production systems.

In order to make dairy products of high quality, high quality raw milk is required. Once raw milk is defective, it cannot be improved through processing or other means, defects often become more pronounced. Therefore, it is important that raw milk be produced and handled from farm to plant under conditions that do not reduce its quality or consequently, the quality of the product. Bacterial counts increase in raw milk due to contamination of and/or growth in the milk. Causes of high bacterialcount include poor pre-milking hygienic methods, inadequate cleaning and sanitization of milk equipment, poor cooling and in some cases, mastitis. Good production and herd management practices help to ensure low bacterial-count and reduce the risk of pathogens contaminating raw milk.

Market-oriented smallholder urban and peri-urban dairy production systems have tremendous potential for development and could play a significant role in minimizing the acute shortage of dairy products in urban centres. However, the complex nature of livestock production, coupled with a low technical base and long
Sci. Technol. Arts Res. J., July-Sep 2014, 3(3): 37-43

generation interval have slowed down the progress in dairy production (Zelalem and Bernard, 2006). Rural smallholders produce about $63 \%$ of the annual total national milk production in mixed farming system of the highlands with small urban/peri-urban producers contributing about $22 \%$ of the total national production. More than three-fourth of the milk produced by rural households is consumed at home (Staal et al., 2008).

The number of bacteria in aseptically drawn milk varies from animal to animal and even from different quarters of the same animal. On an average, aseptically drawn milk from healthy udder contains between 500 and 1000 bacteria/colony $\mathrm{ml}^{-1}$. High initial counts (more than 105 bacteria $\mathrm{ml}^{-1}$ ) are evidence of poor production hygiene (O'Connor, 1994). In proportion to the numbers present, existence of coliform bacteria in milk and milk products is suggestive of faecal contamination and unsanitary practices during production, processing, or storage (Richardson, 1985). Information on the hygienic handling of dairy products is generally lacking and that on their microbial properties is limited. The objective of this research was therefore, to assess dairy production system under peri- urban management conditions of Shambu, Fincha and Kombolcha towns and to characterize raw milk quality produced and retailed by smallholder families.

\section{MATERIAL AND METHODS}

\section{Description of the Study Area}

The study was conducted from August, 2013 to January, 2014 at Shambu, Fincha and Kombolcha towns of Horro-Guduru Wollega zone, Oromia Regional State (Ethiopia). The study area is located in the Western part of Ethiopia, $314 \mathrm{~km}$ west of Addis Ababa, the capital city of the country and the capital of the zone found $64 \mathrm{~km}$ to the North West of the main road from Addis to Nekemte. Horro Guduru Wollega zone is located between 0929'N and $37^{\circ} 26^{\prime} \mathrm{E}$, at an altitude of approximately 2296 m.a.s.l, with a uni-modal rainfall ranging between $1200 \mathrm{~mm}$ $1800 \mathrm{~mm}$ (Olana, 2006). The rainy season occurs from April to mid-October where maximum rain is received in months of June, July and August. Maximum temperature of $23-27^{\circ} \mathrm{C}$ are reached from January to March, and minimum temperature of $7-15^{\circ} \mathrm{C}$ are normal from October to November (CSA, 2006).

\section{Study Animals and Milk Sample}

The classification of the study areas into a peri-urban dairy production system was based on the number of dairy animals that the farms and householders possess and the specialized inputs used (ILRI, 1994). Management of animals (housing, feeding, health care), objective of production (consumption v/s market) and germplasm constituent (exotic breed, cross breed and pure indigenous breed) used for dairy producers were also criteria used to determine the areas' dairy production system. In this study, dairy production systems, dairy cattle feed resources and feeding systems, genetic resource and breeding systems' milk yield and lactation length in peri-urban production was assessed.

\section{Research Design and Methodology}

This study was carried out with the general objective of characterizing the peri-urban dairy production system and determining the quality of raw milk, and specific objective of identifying the potentials and constraints of dairy production. Future prospects of dairying in peri-urban 


\section{Demissu Hundie}

production management and market opportunities in the study zone were also the other objectives designed for the study.

In the primary phase of the study, group discussion was held with key informants (district and municipality livestock development and health agencies) to investigate and have an over view about the overall dairy production system in general, and opportunity and constraints of dairy marketing in particular. The information generated during the key informant discussion phase was used as an input for the preparation and development of a structured questionnaire. Then, questionnaire survey and secondary data was collected from producers and district livestock development and health agencies of the respective study towns.

In the secondary phase of the study, raw milk sample was collected aseptically in sterile bottles from 30 bulk tanks of which fifteen were from producers and fifteen collected from consumers (Hotels and Restaurants). The collected raw milk samples were transported to Holleta Agricultural Research Center's Dairy Microbiology Laboratory within 12 hours of production at a temperature of $<5^{\circ} \mathrm{C}$ using an icebox. Raw milk microbial load was determined by using standard plate count (SPC), coliform count (CC) and preliminary incubation count (PIC).

Standard Plate Count: is the procedure used to measure the general sanitary quality of milk. The standard plate count (SPC) determines the total number of bacteria in a milk sample that can grow and form countable colonies on Standard Methods Agar when incubated aerobically at $32^{\circ} \mathrm{C}\left(90^{\circ} \mathrm{F}\right)$ for 48 hours. It serves as an overall microbial quality index. While the legal maximum for producer milk is $100,000 \mathrm{ml}^{-1}$, ideally SPC values should be less than $10,000 \mathrm{ml}^{-1}$.

Preliminary Incubation Count (PIC): The PIC is performed by holding milk samples at $12.8^{\circ} \mathrm{C}\left(55^{\circ} \mathrm{F}\right)$ for $18 \mathrm{hrs}$ prior to performing the SPC. This incubation temperature selects for bacterial contaminants in a sample that can grow at cooler temperatures, some of which may have the potential for further growth during raw milk storage (Murphy, 1997). The PIC should always be compared to the un-incubated SPC. PIC limits of 3-4 times the SPC, or less than a specific count, such as 50,000 or $100,000 \mathrm{ml}^{-1}$ have been used.

Coliform Count: provides an indication of unsanitary production practices and/or mastitis infection. A count less than 100 colony forming units (CFU) $\mathrm{ml}^{-1}$ is considered acceptable for milk intended to be pasteurized before consumption. Counts of $10 \mathrm{CFUml}{ }^{-1}$ or less are achievable and desirable if raw milk will be consumed directly (Jones and Sumner, 1999 and Ruegg, 2003). The coliform count is performed by plating a sample on Violet Red Bile Agar, a media that selects for coliform bacteria.

\section{Data Sampling, Management and Analysis}

Survey data was collected through personal interviews using three trained enumerators by using survey questionnaire covering measures from resources to parameters reflecting farm functioning. Ninety (90) householders were selected by simple random and purposive sampling for interview. Respondents should have at least one dairy cow at the time of the survey and
Sci. Technol. Arts Res. J., July-Sep 2014, 3(3): 37-43

be able to recall dairy productive history of at least the last calving history of their cow and willing to participate in the study.

A total of 30 raw cow milk samples were collected at three locations (Shambu, Fincha and Kombolcha). At each location, approximately $50 \mathrm{ml}$ of sample from each individual was taken aseptically from the bulk milk container into sterile glass bottles. Raw milk sample was also collected, transported and analyzed following standard procedures (Richardson, 1985). Raw milk in this study refers to unpasteurized whole cow's milk. Raw milk was collected from bulk tank within $15 \mathrm{~min}$ of milking at ambient temperature, labeled with the details of its sources, kept on ice during transport and analyzed immediately after arrival at the laboratory. Then $\log _{10}$ transformation of bacterial count was used before the analysis and each of the analysis was made in duplicates where there were controls for each of them. For survey data analysis, SPSS version 16 software was used for descriptive statistics to describe the various variables assessed in the production system including husbandry, management, inventory of feed types, feeding systems, housing and herd health problems, and dairy cattle reproductive and productive performance.

The number of microorganisms (colony forming unit) per milliliter of milk was calculated using the following mathematical formula (APHA, 1992):

$$
N=\sum c /\left(1 \times n_{1}+0.1 \times n_{2}\right) d
$$

Where $\mathrm{N}$ is the number of colonies per milliliter of milk, $\Sigma c$ is the sum of colonies on plates counted, $n_{1}$ is the number of plates on the lower dilution counted, $\mathrm{n}_{2}$ is the number of plates in the next higher dilution counted and $d$ is the dilution from which the first counts are obtained. All microbial counts were converted to the base -10 logarithm of the number of colony forming units per $\mathrm{ml}$ of raw cow milk samples (log cfu $\mathrm{ml}^{-1}$ ), and from these means their standard deviations were calculated. Data were analyzed using analysis of variance (ANOVA) through the general linear models (GLM) procedure of Statistical Analysis System (SAS) version-9, 2002. The Least Significant Difference (LSD) test was used to separate the means, and mean differences were considered significant at $P<0.05$.

\section{RESULTS AND DISCUSSION}

\section{Dairy Cattle Breeds, Herd Size and Land Holding}

In the study area, different cattle-breeds were reared for dairy purpose. Most of the respondents (74.4\%) kept local indigenous cattle where $25.6 \%$ of them kept cross breed cattle (Table 1). About $62.2 \%$ of respondents had cattle number 1 to $5,24.5 \%$ of respondent's possessed 6 to 10 cattle head and $13.3 \%$ of respondents owned 11 and above cattle. The means and standard deviation of land holding were $0.97 \pm 1.25,0.87 \pm 1.18$ and $0.86 \pm 0.23$ for total landholding, cropland and grazing landholding respectively in the range of none to five hectares per household. Majority of the households in the study area were male-headed where male headed households were 82 that accounted for $91.1 \%$ and female headed household were 8 which was only $8.9 \%$ of the total households studied. 
Table 1: Means and standard deviations of land and cattle breed holding, and household-head gender status

\begin{tabular}{lcc}
\hline Variables & Mean (SD) & Range \\
\hline Landholding per household (ha) & $0.97 \pm 1.25$ & 0 to 5 \\
Crop land (ha) & $0.87 \pm 1.18$ & 0 to 4 \\
Grazing land (ha) & $0.86 \pm 0.23$ & 0 to 1 \\
\hline Cattle Holding & No of Households' & Frequency in (\%) \\
\hline Local cattle owning households' & 67 & 74.4 \\
Cross cattle owning households' & 23 & 25.6 \\
\hline Gender of Households' Heads & & \\
\hline Female-headed households' & 82 & 91.1 \\
Male-headed households' & 8 & 8.9 \\
\hline
\end{tabular}

$\mathrm{ha}=$ hectare, $\mathrm{SD}=$ standard deviation

The peri-urban land holding in this study is comparable to the urban total holding of 1.88 ha used for cropping and cultivation of fodder. However, it was much lower than the peri-urban land holding averaged 2.15 ha for cropping and growing fodder around Hawasa (Anthony Ike, 2002). Therefore, most of the farms of the peri-urban study farms use semi-grazing system where animals are mainly kept on zero grazing and herded on communal grazing lands on the premises of the towns and roadsides.

\section{Reproductive and Productive Performance of Dairy Cattle}

Milk production levels in the peri-urban dairy units ranged from $1.52 \pm 0.858$ to $7.21 \pm 2.347$ litres/cow/day for indigenous and cross breed cows respectively while it was $2.09 \pm 2.195,2.54 \pm 2.048$ and $3.87 \pm 3.521$ for Shambu, Kombolcha and Fincha towns respectively. The highly significant productivity difference $(P<0.001)$ observed among local and cross breed cows is mainly due to breed difference among study animals where particular attention (feeding, housing and health care) was given to the cross breed cows. The relatively higher milk yield per cow at Fincha town and its significant difference might be because of high marketability of raw milk, higher number of cross breed cows owned and better management provided to cows in Fincha compared to Kombolcha and Shambu towns.

In most dairy units, a lactation length of 305 days (10 months) is commonly accepted as a standard. However, such a standard lactation length might not work for dairy cows in the urban and peri-urban areas of East Africa. Both Msanga et al. (2000) in Tanga and Shiferaw et al. (2003) in Addis Ababa reported shorter (8.8 to 9.7 months) and longer (11.1 months) lactation lengths in urban and peri urban dairy units respectively. In this study the (means and SDs) of lactation length of Local and cross breed cows were $10.59 \pm 0.858$ and $11.63 \pm 2.35$ months respectively (Table 2 ). The result agrees with the findings of Shiferaw et al. (2003) for the lactation length of peri-urban cows around Addis Ababa, and the lactation lengths (11 months) reported by Fekadu (1994) in southern Ethiopia. However, the lactation length for both local and cross breed cows, and across the three towns found in this study were higher than the minimum lactation length reported (8.8 to 9.7 months) for peri urban dairy units around Addis Ababa by Shiferaw et al. (2003) and (7.5 months) lactation lengths for peri urban dairy units reported by Ayenew et al. (2009).

Reproductive performance of dairy cows can be measured by considering parameters such as age at puberty, age at first calving (AFC), calving interval (Cl) and number of services per conception (NSC). Management, environmental and physiological factors influence the reproductive performance of lactating dairy cows. Among the most important environmental factors affecting reproductive performance of dairy cows are nutritional status, suckling, milk yield, and season of the year are most common.

Table 2: Means, standard deviations and $P$-values of DMY, LL, AFC, Cl of local cows and cross breed cows of the peri urban areas

\begin{tabular}{lccccc}
\hline \multirow{2}{*}{$\begin{array}{l}\text { Sources of } \\
\text { Variation }\end{array}$} & $\begin{array}{c}\text { Number of } \\
\text { Observation }\end{array}$ & \multicolumn{4}{c}{ Mean \pm St.d. and Level of Significance } \\
\cline { 3 - 6 } & & DMY & LL in Months & AFC in Months & Cl in Months \\
\hline Breed & 63 & $1.52 \pm 0.86$ & $10.59 \pm 0.86$ & $46.22 \pm 12.15$ & $22.09 \pm 8.29$ \\
\hline Local & 19 & $7.21 \pm 2.35$ & $11.63 \pm 2.35$ & $36.68 \pm 12.77$ & $21.47 \pm 14.68$ \\
$\quad$ Cross & & ${ }^{*}$ & Ns & Ns & Ns \\
\hline Location & 31 & $2.09 \pm 2.19$ & $10.53 \pm 1.81$ & $44.0 \pm 16.61$ & $18.04 \pm 6.96$ \\
\hline Shambu & 30 & $3.87 \pm 3.52$ & $10.04 \pm 2.15$ & $42.39 \pm 10.82$ & $24.46 \pm 10.96$ \\
Fincha & 29 & $2.54 \pm 2.05$ & $12.0 \pm 4.77$ & $45.77 \pm 10.32$ & $23.46 \pm 10.83$ \\
Kombolcha & &
\end{tabular}

DMY= Daily milk yield, $\mathrm{LL}=$ Lactation length, $\mathrm{AFC}=\mathrm{Age}$ at first calving, $\mathrm{Cl}=$ calving interval,

Ns $=$ Non significant, ${ }^{*}=$ significant difference at $P<0.05,{ }^{* * *}$ highly significant difference $=P<0.001$.

The means and SDs of age at first calving (AFC) for local and cross breed cows was $46.22 \pm 12.15$ and $36.68 \pm$ 12.77 respectively where as it was significantly $(P<0.05)$ shorter for cross breed heifers. The results of this study were within the ranges of 29.7 and 46 months AFC found around Addis Ababa by Ayenew et al. (2009) and 33.3 \pm 10.90 and $48.9 \pm 8.20$ for Horro-Jersey and Local Horro cows respectively reported by Demissu et al. (2013). However, it was slightly longer than the study result for longer 34.2 months and shorter 32.6 months AFC reported by Lemma and Kebede, (2011) for small and large dairy farms in Addis Ababa. 


\section{Demissu Hundie}

Calving interval is an important factor in measuring the breeding efficiency and directly correlates with the economics of milk production. Reproduction in dairy cows with regular and shorter calving interval (365-420 days) is a key feature for the rapid multiplication of the breeding stocks. However, in this study calving interval extends to two to three years for dairy cattle (Table 2). Long calving interval is a common problem in urban and peri-urban areas and it is linked to poor body condition score and mineral deficiency, especially inorganic phosphorus (Swai et al., 2005). The long mean calving intervals result in low calf crop and low level of production.

\section{Housing, Feeding \& Breeding Management Practices}

Housing in the peri-urban dairy production system was mainly roofed housing where $65.6 \%$ of cows were living
Sci. Technol. Arts Res. J., July-Sep 2014, 3(3): 37-43

under shade while the remaining $34.4 \%$ passed the night in open backyard and/or traditional barn. The muddy and thatch roofed house and backyard barn are favorable for microorganisms to harbor in, which during and before milking could contaminate the milk, milkers' hands and milking equipment. Animals were herded in group mainly on communal grazing land at the premises of towns. Grazing constitutes the basal ration, however, $72.2 \%$ householders were supplementing with roughage (hay, crop residue and stubs). Concentrate feed composed of wheat bran and noug cake (oil cake of Guizotia abyssinica) and salt additionally during the dry season provided mainly to cows and calves. $55.5 \%$ peri-urban dairy producers supplement cows and calves where about $39 \%$ householders supplement lactating cows only.

Table 3: Housing and feeding management tradition of dairy animals

\begin{tabular}{lcc}
\hline Variables & No of Household & Frequencies in (\%) \\
\hline Housing Management & 59 & \\
Roofed housing & 31 & 65.6 \\
Back yard barn & & 34.4 \\
\hline Feed Supplemented & 4 & \\
Roughage only & 65 & 4.4 \\
Roughage, salt and concentrate & 21 & 72.2 \\
Roughage and salt only & & 23.3 \\
\hline Animals supplemented & 50 & \\
Cows and calves & 35 & 55.5 \\
Cows only & 5 & 39.0 \\
All animals & & 5.5 \\
\hline Methods of breeding & 7 & \\
Al only & 60 & 7.8 \\
Natural mating only & 23 & 66.7 \\
Both Al and natural mating & & 25.6 \\
\hline
\end{tabular}

Both natural and artificial insemination (AI) services were used to breed dairy cows. The frequency of using the two breeding systems varies and most dairy farmers use natural service than $\mathrm{Al}$, where $66.67,25.55$ and 7.78 $\%$ producers use natural mating, $\mathrm{Al}$ and both natural mating and Al services respectively. Megersa et al. (2011) reported more than $46.4 \%$ of smallholder dairy farmers in West Shoa use natural service compared to 20.3 percent who use Al service which support this finding. The result implies that smallholder dairy farmers were not satisfied by the Al service delivery that might had technical inefficiency and unavailable when demanded. Generally, housing, feeding and breeding management was poor and increased the vulnerability of dairy product to poor yield with respect to quality and quantity.

\section{Microbial Load of Cows' Raw Milk}

The microbial content of milk indicates the hygienic levels during milking that include cleanliness of the milking utensils, proper storage and transport as well as the wholesomeness of the udder of the individual cow (Spreer, 1998). The most commonly used microbial quality tests for milk and milk products include determination of total bacterial count (TBC) or standard plate count (SPC) and colifom count (CC). Microorganisms can enter milk via the cow, air, feeds, milk handling equipment and the milker. Bacteria in milk, whether originating from the cow or the environment, can significantly affect the quality of dairy products and therefore consumer acceptance. Once they get into the milk their numbers increase rapidly. It is therefore more effective to exclude microorganisms than trying to control their growth once they get access into the milk.

Table 4 shows the microbial counts of cows' raw milk produced in the study area. The total bacterial count obtained in this study was generally high as compared to the acceptable level of $1 \times 10^{5}$ bacteria per ml of raw milk (O'Connor, 1994). The overall means and standard deviations of total bacterial count of cows' raw milk found in this study among the three locations was minimum $9.62 \pm 0.31 \log _{10} \mathrm{cfu} \mathrm{ml} l^{-1}$ for Fincha and maximum 9.78 \pm $0.38 \log _{10} \mathrm{cfu} \mathrm{ml}^{-1}$ for Kombolcha town. At producers and consumers level, the minimum $(9.52 \pm 0.56)$ and maximum $(9.95 \pm 0.31)$ standard plate counts were recorded, both were higher than the minimum and maximum total bacterial counts of cows' raw milk produced in southern region ( 6 to $8.8 \log 10 \mathrm{cfu} \mathrm{ml}^{-1}$ ) reported by Fekadu (1994). Similarly, the result was still much higher than $7.4 \times 10$ and $2.0 \times 10 \mathrm{cfu} \mathrm{ml}^{-1}$ total bacterial count of cows' milk produced in Bila Sayo and Guto Wayu districts respectively in eastern Wollega zone reported by Alganesh, (2002). The SPC of this study is again higher than the recent study report by Asaminew and Eyassu, (2010) where the overall mean total bacterial count was found to be $7.58 \log 10 \mathrm{cfu} \mathrm{ml}^{-1}$ cows' milk produced in Bahr Dar Zuria district. 
Table 4: Overall means and SDs of bacterial counts (log10) per $\mathrm{ml} / \mathrm{g}$ of raw milk samples collected

\begin{tabular}{|c|c|c|c|c|c|}
\hline \multirow{2}{*}{\multicolumn{2}{|c|}{ Source of Variation }} & \multirow{2}{*}{$\begin{array}{c}\text { No of } \\
\text { observation }\end{array}$} & \multirow{2}{*}{$\begin{array}{c}\text { SPC }\left(\log _{10} \mathrm{cfu} / \mathrm{ml}\right) \\
(\text { Mean } \pm \text { SD) }\end{array}$} & \multirow{2}{*}{$\begin{array}{c}\mathrm{CC}\left(\log _{10} \mathrm{cfu} / \mathrm{ml}\right) \\
(\text { Mean } \pm \mathrm{SD})\end{array}$} & \multirow{2}{*}{$\begin{array}{c}\text { PIC }\left(\log _{10} c f u / m l\right) \\
\text { (Mean } \pm \text { SD })\end{array}$} \\
\hline & & & & & \\
\hline \multirow[t]{4}{*}{ Location } & & & $\mathrm{Ns}$ & $\star *$ & $\mathrm{Ns}$ \\
\hline & Shambu & 10 & $9.73 \pm 0.49$ & $5.6 \pm 0.38$ & $9.95 \pm 0.32$ \\
\hline & Fincha & 10 & $9.62 \pm 0.31$ & $5.7 \pm 0.09$ & $10.0 \pm 0.26$ \\
\hline & Kombolcha & 10 & $9.78 \pm 0.38$ & $5.4 \pm 0.33$ & $9.98 \pm 0.36$ \\
\hline \multirow[t]{7}{*}{ Sample } & & & Ns & ** & Ns \\
\hline & S. producers & 5 & $9.95 \pm 0.31$ & $5.4 \pm 0.45$ & $9.66 \pm 0.14$ \\
\hline & S. consumer & 5 & $9.52 \pm 0.56$ & $5.8 \pm 0.16$ & $10.23 \pm 0.01$ \\
\hline & F. producer & 5 & $9.58 \pm 0.36$ & $5.7 \pm 0.06$ & $10.16 \pm 0.16$ \\
\hline & F. consumers & 5 & $9.66 \pm 0.28$ & $5.8 \pm 0.13$ & $9.92 \pm 0.31$ \\
\hline & K. producers & 5 & $9.68 \pm 0.46$ & $5.3 \pm 0.46$ & $9.90 \pm 0.40$ \\
\hline & K. consumers & 5 & $9.89 \pm 0.31$ & $5.4 \pm 0.09$ & $10.06 \pm 0.35$ \\
\hline
\end{tabular}

The overall means and standard deviations of coliform count of cows' raw milk produced in Shambu, Fincha and Kombolcha were $5.6 \pm 0.38,5.7 \pm 0.09$ and $5.4 \pm 0.33 \log _{10}$ cfu $\mathrm{ml}^{-1}$ respectively (Table 4 ). The result obtained in the current study is higher than that reported by Fekadu (1994) who found Coliform count (CC) of 3.8, 4.0 and 3.8 log cfu ml ${ }^{-1}$ for cows' milk produced in Aneno, Gulgula and Dongora districts of southern region, respectively. However, the coliform count in this study is lower than $6.57 \mathrm{log}$ cfu $\mathrm{ml}^{-1} \mathrm{CC}$ reported for cows' milk collected from different producers in the central highland of Ethiopia by Zelalem and Bernard (2006). There was significant difference $(P<0.05)$ in coliform count of cows' raw milk between the three study towns and among producers and consumers of the study towns.

The higher coliform count observed in this study may be due to the initial contamination of the milk samples either from the cows, the milkers, milk containers, muddy and poorly cleaned ground of cows' barn and the milking environment. Thus, extension services and training of producers and retailers on improved milk handling practices are required to improve the raw milk quality in the study area. The means and standard deviations of preliminary incubation count (PIC) were 9.95 \pm 0.32 , $10.0 \pm 0.26$ and $9.98 \pm 0.36$ for Shambu, Fincha and Kombolcha towns respectively. The PIC of cows' raw milk sample studied had no significant difference among study towns and among producers and consumers too. The bacterial colony forming units were found to be higher than the SPC for the three towns and samples of producers and consumers which indicates that cold loving bacteria are found in the study area.

\section{CONCLUSIONS}

This study showed that under peri-urban dairy production system, animal feeding was mainly based on semi-grazing, where housing was thatch roofed and earthen ground that mainly constrain milk quality, and breeding system was mainly natural mating dependent. Dairy productivity for both local cows and cross breed dairy animals was below the productivity average of dairy cows under same production system. Age at first calving, lactation length and calving intervals were highly extended that affected the lifetime productivity of individual cow.

Bacteriological quality of raw cow milk produced by smallholder dairy farms in the study area was substandard and was attributed to unsanitary practices and lack of dairy facilities. The high count in preliminary incubation count (PIC) was an indication of the existence of cold loving bacteria in the study area. Significant differences in coliform count of milk were observed among study location, dairy producers and consumers that indicates variations in hygienic and sanitary practices of householders and consumers at different levels and existence of mastitis.

\section{ACKNOWLEDGEMENTS}

The author would like to express his heartfelt thanks to the respondents of Shambu, Fincha and Kombolcha towns for their unreserved co-operation in providing data and willingness to exchange information. The quality and accuracy of the survey data collected is due to the active contribution of Mitiku Bongasie and Misgana Abdeta, the enumerators. Wollega University's Research Directorate is dully acknowledged for budget allocation.

\section{REFERENCES}

Ahmed, M.M., Ehui, S. and Yemesrach Assefa. (2004). Dairy development in Ethiopia. International Food Policy Institute. Available on: http://www.ifpri.org/dius/eptd/dp/ papers/eptdp123pdf.

Alganesh Tola. (2002). Traditional milk and milk product handling practice and raw milk quality in eastern Wollega. M.Sc. Thesis Alemaya University, Dire Dawa, Ethiopia.

American Public Health Association (APHA) 1992. Standard Method for the examination of dairy products. $16^{\text {th }}$ ed., APHA, Washington.

Anthony Ike. (2002). Urban dairying in Awassa, Ethiopia. http://www.troz.uni-ohenheim.de/research/Thesis/MScAP.

Ayenew Y.A., Wurzinger, M., Tegegne, A. and Zollitsch, W. (2009). Handling, processing and marketing of milk in the North western Ethiopian highlands. Livestock Research for Rural Development 21(7): Article \#97 http://www.Irrd.org /Irrd21/7/ayen21097.htm

Demissu, H., Fekadu, B. and Gemeda, D. (2013). Early Growth and Reproductive Performances of Horro Cattle and their F1 Jersey Crosses in and around Horro-Guduru Livestock Production and Research Center. Science, Technology and Arts Research Journal 2(3):134-141.

Fekadu, B. (1994). Present Situation and Future Aspects of Milk Production, Milk Handling and Processing of Dairy Products in Southern Ethiopia. 1. Chemical and Microbial Quality. A PhD Thesis presented to the Department of 


\section{Demissu Hundie}

Food Science of Agricultural University of Norway, Norway.

IDF. (1994). Recommendations for the hygienic manufacture of milk and milk based products. Bulletin of the International Dairy Federation (IDF) 292: 32.

ILCA. (1992). Alternative milk processing and preservation techniques and the quality of market butter and cheese. Annual program report 1991. International Livestock Centre for Africa. Addis Ababa, Ethiopia. pp. 39-40.

Lemma, A. and Kebede, S. (2011). The effect of mating systems and herd size on reproductive performance of dairy cows in market oriented urban dairy farming in and around Addis Ababa. Revue de Médecine Vétérinaire 162: $526-530$

Mlozi, M.R.S. (2005). Urban animal agriculture: its palliativity and reasons for persistence in Tanzanian towns. RICS Foundation pp. $26 \mathrm{http} / /$ :www.rics-foundation.org.

Msanga, Y.N., Bryant, M.J., Rutamu, I.B., Minja, F.N and Zylstra, L. (2000). Effect of environmental factors and the proportion of Holstein blood on milk yield and lactation length of cross breed dairy cattle on smallholder farms in northeast Tanzania. Tropical Animal Health and Production 32(1): 23-31.

Msangi, B.S.J., Bryant, M.J. and Thorne, P.J. (2005). Some factors affecting reproductive success in cross breed dairy cows on smallholder farms in coastal North-East Tanzania. Tropical Animal Health and Production 37(5): 413-426.

Murphy, S.C. (1997). Raw milk bacteria tests: Standard plate count, preliminary incubation count, lab pasteurization count and coliform count - What do they mean for your farm? page 34-42 in Proceedings of National Mastitis Council Regional Meeting, Syracuse, NY.
Sci. Technol. Arts Res. J., July-Sep 2014, 3(3): 37-43

O'Connor, C.B. (1994). Rural small holder milk production and utilization, and the future for dairy development in Ethiopia. Pp. 123-130. Proceedings of symposium on Dairy Marketing in sub Saharan Africa, 26-30 Nov.1990,ILCA (International Livestock Center for Africa), Addis Ababa, Ethiopia.

Olana, B.T. (2006). People and Dams: Environmental and socio- economic changes induced by a reservoir in Finca'a water shade Western Ethiopia. PhD Thesis, Wageningen University, The Netherlands.

SAS (2002). Statistical Analysis System. SAS for Windows, Release 9.1(2002-2003) SAS Information Inc., Cary, NC, USA.

Shiferaw, Y., Tenhagn, B.A., Bekana, M. and Kassa, T. (2003). Reproductive performance of cross breed dairy cows in different production systems in the central Highlands of Ethiopia. Tropical Animal Health and Production 25: 551-61

SPSS (Statistical Package for Social Sciences). SPSS version 16 application guide. SPSS Inc.

Staal, S.J., Pratt, A.N., Jabbar, M. (2008). Dairy Development for the Resource Poor Part II: Kenya and Ethiopia Dairy Development Case Studies. PPLPI (Pro-poor Livestock Policy Initiative) Working Paper No. 44-2. ILRI (International Livestock Research Institute), Nairobi, Kenya.

Yilma, Z. and Faye, B. (2006). Handling and Microbial Load of Cow's Milk and Irgo -Fermented Milk Collected from Different Shops and Producers in Central Highlands of Ethiopia. Ethiopian Journal of Animal Production 6(2): 6782. 